\title{
Analisa Penerapan Perhitungan Rekonsoliasi Fiskal Terhadap Laporan Keungan Komersial
}

\author{
Deddy Dariansyah \\ Universitas IndraPrasta PGRI \\ deddyjogjazz@yahoo.co.id
}

\begin{abstract}
The calculation of fiscal reconciliation made by the company (taxpayer) due to differences in calculations, especially profit by commercial accounting and taxable profit (fiscal). to bridge the existence of differences in commercial financial statements and fiscal financial statements for more efficient then fiscal Financial Statements prepared in tandem with commercial financial statements, meaning that although commercial or business financial statements are prepared on the basis of business accounting principles, but the provision of taxation is dominant in the process of reporting the preparation of reports finance. The causes of differences in commercial financial statements and fiscal financial statements are due to differences in accounting principles, accounting methods and procedures, differences in income and expense recognition, as well as differences in income and expense treatment.. In addressing the differences that occur between the Commercial Income Statement and the Fiscal Income Statement, based on the Financial Accounting Standards and the applicable tax law, based on the results of research and calculation analysis of the calculation of fiscal reconciliation to the Financial Statement of profit
\end{abstract}

Keywords: Reconciliation Fiscal, Financial Statement, Tax Law

\begin{abstract}
Abstrak
Perhitungan rekonsiliasi fiskal yang dilakukan oleh perusahaan (pembayar pajak) karena perbedaan perhitungan, terutama laba dengan akuntansi komersial dan laba kena pajak (fiskal). Untuk menjembatani adanya perbedaan dalam laporan keuangan komersial dan laporan keuangan fiskal untuk Laporan Keuangan fiskal yang lebih efisien dan kemudian disusun bersama dengan laporan keuangan komersial, yang berarti bahwa meskipun laporan keuangan komersial atau bisnis disusun berdasarkan prinsip akuntansi bisnis, tetapi ketentuan perpajakan dominan dalam proses pelaporan penyusunan laporan keuangan. Penyebab perbedaan dalam laporan keuangan komersial dan laporan keuangan fiskal adalah karena perbedaan dalam prinsip akuntansi, metode dan prosedur akuntansi, perbedaan pendapatan dan pengakuan biaya, serta perbedaan dalam pendapatan dan biaya perawatan .. Dalam mengatasi perbedaan yang terjadi antara Laporan Laba Rugi Komersial dan Laporan Penghasilan Fiskal, berdasarkan Standar Akuntansi Keuangan dan undang-undang pajak yang berlaku, berdasarkan hasil penelitian dan analisis perhitungan dari perhitungan rekonsiliasi fiskal terhadap Laporan Keuangan laba
\end{abstract}

Kata kunci: Rekonsiliasi Fiskal, Laporan Keuangan, Hukum Pajak

Diterima: 11 Agustus 2018; Revisi: 2018; Disetujui: 2018 


\section{PENDAHULUAN}

Setiap Perusahaan di Indonesia saat ini telah memiliki Laporan Keuangan setiap tahunnya yang bertujuan untuk mengetahui kinerja suatu perusahaan, selain itu juga Laporan Keuangan perusahaan tersebut dipergunakan juga untuk melapor dan membuat perhitungan dalam membayar pajaknya. Rekonsiliasi Fiskal dalam laporan keuangan perusahaan yang dibuat oleh Perusahaan (Wajib Pajak) terjadi karena adanya perbedaan perhitungan, khususnya laba menurut akutansi (komersial), dengan perhitungan laba menurut Perpajakan (fiskal). Laporan Keuangan disusun berdasarkan berdasarkan prinsip yang berlaku umum, yaitu Standar Akutansi Keuangan (SAK), sedangkan untuk kepentingan fiskal, Laporan Keuangan disusun berdasarkan Peraturan Perpajakan (Undang Undang Pajak Penghasilan). Untuk mengatasi perbedaan tersebut digunakan beberapa pendekatan dalam penyusunan laporan keuangan fiskal, yaitu: (1) Laporan Keuangan fiskal disusun secara beriringan dengan laporan keuangan komersial, artinya meskipun laporan keuangan komersial atau bisnis disusun berdasarkan prinsip akutansi bisnis, tetapi ketentuan perpajakan sangat dominan dalam mendasari proses penyusunan laporan keuangan; (2) Laporan keuangan fiskal disusun dengan menyisipkan ketentuan ketentuan pajak dalam laporan keuangan bisnis, artinya pembukuan yang diselenggarakan perusahaan didasarkan perusahaan didasarkan pada prinsip akutansi bisnis, tetapi jika ada ketentuan perpajakan yang tidak sesuai dengan prisnip akautansi bisnis maka diprioritaskan adalah ketentuan Perpajakan.

Untuk menjembatani adanya perbedaan dalam laporan keuangan komersial dan laporan keuangan fiskal agar lebih efesiensi maka Laporan Keuangan fiskal disusun secara beriringan dengan laporan keuangan komersial, artinya meskipun laporan keuangan komersial atau bisnis disusun berdasarkan prinsip akutansi bisnis, tetapi ketentuan perpajakan sangat dominan dalam mendasari proses penyusunan laporan keuangan. Penyebab perbedaan laporan keuangan komersial dan laporan keuangan fiskal adalah karena terdapat perbedaan prinsip akutansi, metode dan prosedur akutansi, perbedaan pengakuan penghasilan dan biaya, serta perbedaan perlakuan penghasilan dan biaya. 
Dalam menyikapi perbedaan-perbedaan yang terjadi antara Laporan Keuangan Laba Rugi Komersial dan Laba Rugi Fiskal, berdasarkan Standar Akuntansi Keuangan dan serta Undang-Undang perpajakan yang berlaku, atas dasar inilah penulis ingin meneliti untuk menganalisa Penerapan Perhitungan Rekonsiliasi Fiskal Terhadap Laporan Keuangan Komersial pada PT XYZ.

\section{METODE}

Metode penelitian ini menggunakan pendekatan Deskriptif Kualitatif, dalam penelitian ini bersifat Deskriptif Kualitiatif yaitu mendeskripsikan tentang Rekonsiliasi Fiskal atas Laporan Keuangan komersial, serta mengumpulkan sejumlah data data pendukung untuk mendapatkan gambaran fakta-fakta yang jelas tentang hal keadaan Laporan Keuangan Tahun 2016 pada PT XYZ tersebut. Pengertian Metode deskriptif Sugiyono (2013) adalah Metode deskriptif adalah metode yang digunakan untuk menggambarkan atau menganalisis suatu hasil penelitian tetapi tidak digunakan untuk membuat kesimpulan yang lebih luas. Sedangkan menurut Sugiyono (2013) Metode penelitian kuantitatif dapat diartikan sebagai metode penelitian yang berlandaskan pada filsafat positivisme, digunakan untuk meneliti pada populasi atau sampel tertentu. Teknik pengambilan sampel pada umumnya dilakukan secara random, pengumpulan data menggunakan instrumen penelitian, analisis data bersifat kuantitatif/statistik dengan tujuan untuk menguji hipotesis yang telah ditetapkan.

Metode Pengumpulan Data yaitu pengumpulan data dilakukan untuk memperoleh informasi yang dibutuhkan dalam rangka mencapai tujuan.Dalam proses pengumpulan data yang diperlukan, penulis menggunakan 2 (dua) teknik pengumpulan data yaitu; (1) Interview, yaitu mengadakan wawancara dalam hal ini tanya jawab dengan pimpinan dan pegawai PT XYZ yang ditujukan untuk mengadakan penelitian terhadap tata cara pelaporan yang menyangkut masalah tersebut; (2) Dokumenter, cara pengumpulan data dengan menggunakan arsip dan dokumen-dokumen dari perusahaan yang bersangkutan. 
Metode Analisis yang digunakan penulis dalam menyelesaikan permasalahan dalam penelitian ini adalah dengan menggunakan analisis deskriptif kualitatif. Proses analisis merupakan proses awal dalam tahap perencanaan penyelesaian suatu masalah, di dalam penelitian ini, penulis akan mempelajari Laporan Keuangan yang diperoleh dari PT XYZ kemudian dianalisa apakah proses rekonsiliasi fiskal yang dibuat tersebut sudah benar dan telah sesuai dengan peraturan Pajak yang berlaku di Indonesia saat ini.

\section{HASIL DAN PEMBAHASAN}

Dalam penelitian dan pembahasan ini Rekonsiliasi fiskal dilakukan berdasarkan dari laporan laba rugi komersial yang disusun oleh Wajib Pajak. Laba (rugi) komersial tersebut dilakukan koreksi fiskal sehingga menghasilkan laba (rugi) fiskal atau sering disebut penghasilan neto fiskal. Dalam melakukan koreksi fiskal yang akan dikoreksi adalah laporan Laba rugi komersial yang dibuat oleh perusahaan berdasarkan standar akuntansi yang berlaku, untuk dilakukan Rekonsiliasi fiskal berdasarkan peraturan perpajakan yang berlaku saat ini. Dimana penelitian akan dilakukan pada Laporan laba rugi komersial yang dibuat oleh PT XYZ berdasarkan standar akuntansi. Berikut ini yang akan menjadi fokus penelitian untuk analisis Rekonsiliasi Fiskal dalam rangka perhitungan pajak penghasilan badan pada laporan laba-rugi periode 1 Januari - 31 Desember 2016 adalah sebagai berikut:

Nama Wajib Pajak

\section{: PT XYZ}

Jenis Usaha

: Perdagangan besar

\section{Laporan Rugi Laba Tahun 2016}

\section{(dalam Rupiah)}

Penjualan Bruto Rp 9.500.000.000

HPP Rp 7.800.000.000

Laba Bruto Usaha $\quad$ Rp 1.700.000.000

\section{Biaya Usaha}

1. Gaji, bonus THR dan pesangon

Rp 120.000.000

2. $\mathrm{PPH} 21$

$\mathrm{Rp} \quad 6.000 .000$ 
3. Biaya pengangkutan

Rp $\quad 40.000 .000$

4. Biaya Pemasaran

Rp 20.000.000

5. Biaya member Golf

Rp 30.000.000

6. Biaya pelatihan pegawai

Rp 70.000.000

7. Biaya jasa pemeliharaan

Rp 80.000.000

8. Sewa gedung kantor

Rp $\quad 60.000 .000$

9. Biaya reprerasi dan pemeliharaan gedung

Rp 50.000.000

10. Penghapusan piutang tertagih

Rp 45.000.000

11. Biaya perjalanan dinas

Rp 35.000.000

12. Biaya jamuan tamu

Rp 54.000.000

13. Biaya listrik, air, dan telp

Rp 35.000 .000

14. Sumbangan HUT RI

Rp 100.000.000

15. Biaya alat kantor

Rp 75.000.000

16. Biaya pakaian seragam satpam dan Keselamatan

Rp $\quad 60.000 .000$

17. $\mathrm{PKB}, \mathrm{PBB}$ bea materai

Rp 30.000.000

18. Biaya makan minum karyawan

Rp 20.000.000

19. Penyusutan aktiva tetap

Rp 20.000.000

20. Premi asuransi kebarakan

Rp 25.000.000

21. Premi asuransi jiwa

Rp 15.000 .000

22. Premi asuransi kesehatan

Rp 20.000.000

23. Biaya pengobatan rumah sakit

Rp 30.000.000

24. Bantuan utk masyarakat sekitar

Rp 40.000 .000

25. Biaya rekreasi

$\underline{\mathrm{Rp} \quad 50.000 .000}$

Total Biaya usaha

Rp 1.040.000.000

\section{Biaya Luar Usaha:}

Biaya perawatan gedung yg disewakan

Rp 20.000.000

Biaya pengurusan tanah yg dijual

Rp 35.000.000

Rugi selisih kurs

Rp 15.000 .000 
Total biaya luar usaha

Rp 70.000 .000

\section{Pendapatan lain lain}

Sewa Gedung

Rp 90.000 .000

Penjualan tanah

Rp 80.000.000

Sewa mesin

Rp 40.000 .000

Bunga deposito

Rp 25.000.000

Dividen

Rp 50.000.000

Total pendapatan lain lain

$\underline{\operatorname{Rp~285.000.000}}$

Laba Neto Usaha tahun 2016

Rp 875.000.000

\section{Sumber Laporan Keuangan PT XYZ}

\section{Keterangan tambahan}

a. Penghapusan piutang karena tidak ditemukan lagi orangnya dan alamatnya sudah pindah

b. Biaya pengobatan dibayarkan kpd klinik yg punya kerjasama dengan perusahaan

c. Dividen diterima dari pemegang saham sebanyak $40 \%$

d. Harga pokok penjualan :

Persediaan barang dagangan , 1 januari $2016 \quad$ Rp 1.500.000.000

Pembelian barang dagangan $\quad$ Rp 9.000.000.000

Persediaan barang dagangan 31 des $2016 \quad \underline{\text { Rp 2.700.000.000 }}$

Rp 7.800.000.000

e. Aktiva tetap per 1 januari 2016 dan penyusutan metode garis lurus

\begin{tabular}{lll}
\hline Jenis aktiva tetap & Tahun perolehan & Harga perolehan \\
\hline Kelompok 1 & $12-12-2013$ & 48.000 .000 \\
Kelompok 2 & $05-07-2012$ & 100.000 .000 \\
Kelompok 3 & $19-06-2011$ & 200.000 .000 \\
Bangunan permanen & $05-09-2010$ & 1.000 .000 .000 \\
\hline
\end{tabular}

f. Pajak pajak thn 2016

1. Pph pasal 21 pembayaran gaji karyawan $\mathrm{Rp} 6.000 .000$

2. Pph 22 dipungut oleh bendharawan pemerintah Rp 25.000.000 
3. Pph 23 yg dipungut pihak lain $\mathrm{Rp} 600.000$

4. Pph 25 Rp 18.000 .000

5. Pph pasal 4 ayat 2 Rp 6.000 .000 atas sewa gedung

6. Pasal 4 ayat 2 Rp 9.000 .000 atas sewa gedung

Berdasarkan analisa Laporan Keuangan PT XYZ di Tahun 2016 laba Neto Usaha tahun 2016 Rp875.000.000, berdasarkan Standar Akutansi Keuangan yang belaku tanpa melakukan perhitungan Rekonsiliasi Fiskal sesuai dengan peraturan undang undang Pajak yang berlaku. Sebelum membuat Laporan Rekonsiliasi Fiskal Pajak terhadap Laporan Keuangan PT XYZ Tahun 2016, diperlukan membuat perhitungan Rekonsiliasinya sebagai berikut:

1. Penjualan Bruto

Rp 9.500.000.000

HPP

$\underline{\text { Rp 7.800.000.000 }}$

Rp 1.700.000.000

Laba usaha merupakan objek pajak pasal 4 ayat 1 huruf c UU PPH

2. Gaji bonus THR dan pesangon Rp 120.000.000

biaya fiskal pasal 6 ayat 1 huruf a UU PPH

pembayaran tsb bukan biaya fiskal apabila diambil dari jumlah laba.

3. Pph pasal 21 sebsar Rp 6.000.000

Bukan biaya fiskal sesuai pasal 6 ayat 1 huruf a UU PPH angka 9. pasal 21 merupakan PPH yg dipotong dari gaji dan beban pegawai. Demikian pula apabila PPH pasal 21 tersebut ditanggung pemberi kerja juga bukan biaya fiskal.

Berbeda dengan tunjangan PPH pasal 21 yg merupakan biaya fiskal karena termasuk tambahan gaji dan harus dimasukkan sebagai objek pph pasal 21

4. Biaya pengangkutan sebesar $\mathrm{Rp} 40.000 .000$

Biaya fiskal sesuai pasal 6 ayat 1 huruf a UU PPH

5. Biaya pemasaran sebesar Rp 20.000.000

Biaya fiskal sesuai dg pasal 6 ayat 1 huruf a UU PPH

6. Biaya member golf sebesar $\mathrm{Rp} 30.000 .000$

Bukan biaya fiskal sesuai pasal 9 ayat 1 huruf b UU PPH 
7. Biaya pelatihan pegawai sebesar $\mathrm{Rp} 70.000 .000$ Biaya fiskal sesuai pasal 6 ayat 1 huruf g UU PPH

8. Biaya jasa pemeliharaan Rp 80.000.000 Biaya fiskal sesuai dg pasal 6 ayat 1 huruf a Sewa gedung kantor sebesar Rp 60.000.000 Biaya fiskal sesuai pasal 6 ayat 1 Biaya pemeliharaan gedung kantor Rp 50.000.000 Biaya fiskal sesuai pasal pasal 6 ayat 1 hruf a Penghapusan piutang tak tertagih Rp 45.000.000

Bukan biaya fiskal sesuai pasal 6 ayat 1 huruf h, karena tdk memenuhi syarat sebagaimana tercantum dlm pasal tersebut

Biaya perjalanan dinas sebesar Rp 35.000.000

Biaya fiskal sesuai pasal 6 ayat 1 huruf a

Biaya jamuan tamu Rp 55.000.000

Biaya fiskal sesuai pasal 6 ayat 1 huruf a UU PPH sepanjang telah dibuatkan daftar nominative

Biaya listrik air telepon $\mathrm{Rp} 35.000 .000$

Biaya fiskal sesuai pasal 6 ayat 1 huruf a, sepanjang utk usaha dan bukan utk mess karyawan, sedangkan biaya telepon seluler diatur dalam kep Dirjen No 220 / PJ / 2002 dg pembebanan biaya fiskal sebesar 50\%

Sumbangan HUT RI sebesar Rp 10.000.000

Bukan biaya fiskal karena sumbangan yg diperkenankan sebagai biaya terbatas utk bencana nasional, infrastrukur sosial, fasilitas pendidikan dan pembinaan olahraga sesuai pasal 6 ayat 1 huruf I

Biaya alat kantor sebesar Rp 75.000.000

Biaya fiskal sesuai pasal 6 ayat 1 huruf UU PPH

Biaya pakaian seragam satpam \& keselamatan kerja Rp 60.000.000

Biaya fiskal sesuai pasal 6 ayat 1 huruf a UU PPH, pasal 9 ayat 1 huruf e, permenkeu No 83/ PMK/03/2009

PKB, PBB bea materai Rp 30.000.000

Biaya fiskal sesuai pasal 6 ayat 1 huruf I SE DJP no 1 dan 2 / PJ 42/ 2002 
Biaya makan minum karyawan Rp 20.000.000

Biaya fiskal pasal 6 ayat 1 huruf a, pasal 9 ayat 1 huruf e

Penyusutan aktiva tetap Rp 20.000.000

Biaya fiskal sepanjang aktiva tetap tersebut milik perusahaan dan digunakan utk kegiatan usaha. Penghitungan penyusutan sesuai pasal 11 UU PPH. Kurang disusutkan/ koreksi negative sebesar Rp 66.000.000

\begin{tabular}{lll}
\hline Jenis aktiva tetap & Tahun perolehan & Harga perolehan \\
\hline Kelompok 1 & $12-12-2013$ & 48.000 .000 \\
Kelompok 2 & $05-07-2012$ & 100.000 .000 \\
Kelompok 3 & $19-06-2011$ & 200.000 .000 \\
Bangunan permanen & $05-09-2010$ & 1.000 .000 .000
\end{tabular}

Kelompok 1 disusutkan 4 tahun ( 48 bulan ) berakhir tahun 2017, disusutkan 1 bulan thn 2017, 12 bulan masing masing thn 2013 s.d thn 2017, dan 11 bulan thn 2017 ( thn terakhir penyusutan), penyusutan thn 2016=11/12 x $25 \% \mathrm{xp}$ 48.000.000 = Rp 11.000.000

Kelompok II disusutkan 8 tahun berakhir thn 2020, sehingga penyusutan thn $2016=12.5 \%$ x Rp 100.000.000 = Rp 12.500.000

Kelompok III disusutkan 16 tahun berakhir 2024, sehingga penyusutan thn 2016= $6,25 \%$ x Rp $200.000 .000=\operatorname{Rp} 12.500 .000$

Bangunan permanen disusutkan 20 tahun berakhir thn 2030 sehingga penyusutan thn 2016

$=5 \% \times \operatorname{Rp} 1.000 .000 .000=\operatorname{Rp} 50.000 .000$

Total penyusutan fiskal thn 2016 sebesar Rp 11 juta + Rp 12,5 juta $+12,5$ juta +50 juta $=\operatorname{Rp} 86.000 .000$

Premi asuransi kebakaran sebesar Rp 25.000.000

Biaya fiskal sesuai pasal 6 ayat 1 huruf a

Premi asuransi jiwa Rp 15.000.000

Bukan biaya fiskal sepanjang tdk dimasukkan sebagai objek pph pasal 21 dan, akan menjadi biaya fiskal apabila telah masuk sbg objek pph 21 sesuai penjelasan pasal 6 ayat 1 huruf a

Premi asuransi kesehatan Rp 20.000.000 
Bukan biaya fiskal sepanjang tdk dimasukkan sbg objek pph pasal 21, dan akan menjadi biaya fiskal apabila telah masuk sbg objek pasal 21 sesuai penjelasan 6 ayat 1

Biaya pengobatan rumah sakit Rp 30.000 .000

Bukan biaya fiskal sesuai dg pasal 9 ayat 1 huruf e

Bantuan utk masyarakat sekitar Rp 40.000.000

Bukan biaya fiskal karena sumbangan yg diperkenankan sbg biaya terbatas utk bencana nasional, litbang di Indonesia dll

Biaya rekreasi Rp 50.000.000

Bukan biaya fiskal karena biaya tsb tdk terkait dg kegiatan usaha pasal 6 ayat 1 huruf a

Biaya perawatan gudang yg disewakan Rp 20.000.000

Bukan biaya fiskal sesuai PP no 94 thn 2010 karena terkait dengan penghasilan sewa gudang.

Biaya pengurusan tanah dijual Rp 35.000.000

Bukan biaya fiskal sesuai dg peraturan pemerintah no 94 thn 2010, karena terkait dg penghasilan sewa gudang yg dikenakan PPH Final

Rugi selisih kurs Rp 15.000.000

Biaya fiskal sesuai pasal 6 ayat 1 huruf e sepanjang terkait dg kegiatan usaha

Pendapatan sewa gudang Rp 90.000.000

Objek pajak PPH final pasal 4 ayat 2

Laba penjualan tanah Rp 80.000.000

Objek pajak PPH final pasal 4 ayat 2

Sewa mesin Rp 40.000.000

Sewa mesin merupakan objek PPH dan tidak termasuk objek PPH final sehingga terutang PPH atas dasar Penghasilan neto pasal 4 yat 1 huruf $i$

Bunga Deposito dari bank Rp 25.000.000

Objek PPH final pasal 4 ayat 2

Deviden sebesar Rp 50.000.000

Bukan objek PPH sesuai pasal 4 yat 3

PT XYZ 


\section{Laporan Rekonsiliasi Fiskal Tahun 2016}

\begin{tabular}{|c|c|c|c|c|}
\hline Pos rekening & $\begin{array}{c}\text { Lap keu } \\
\text { komersial }\end{array}$ & Koreksi + & Koreksi - & Lap keu fiskal \\
\hline Penjualan & 9.500 .000 .000 & & & 9.500 .000 .000 \\
\hline HPP & 7.800 .000 .000 & & & 7.800 .000 .000 \\
\hline Laba bruto & 1.700 .000 .000 & & & 1.700 .000 .000 \\
\hline \multicolumn{5}{|l|}{ Biaya usaha } \\
\hline Gaji bonus THR & 120.000 .000 & & & 120.000 .000 \\
\hline PPH 21 & 6.000 .000 & 6.000 .000 & & 0 \\
\hline Biaya pengangkutan & 40.000 .000 & & & 40.000 .000 \\
\hline Biaya pemasaran & 20.000 .000 & & & 20.000 .000 \\
\hline Biaya member golf & 30.000 .000 & 30.000 .000 & & 0 \\
\hline Biaya pelatihan & 70.000 .000 & & & 70.000 .000 \\
\hline $\begin{array}{l}\text { Biaya jasa } \\
\text { pemeliharaan }\end{array}$ & 80.000 .000 & & & 80.000 .000 \\
\hline Sewa gedung kantor & 60.000 .000 & & & 60.000 .000 \\
\hline $\begin{array}{l}\text { Biaya repreasi dan } \\
\text { pemeliharaan }\end{array}$ & 50.000 .000 & & & 50.000 .000 \\
\hline $\begin{array}{l}\text { Penghapusan piutang } \\
\text { tak tertagih }\end{array}$ & 45.000 .000 & 45.000 .000 & & 0 \\
\hline Biaya perjalanan dinas & 35.000 .000 & & & 35.000 .000 \\
\hline Biaya jamu tamu & 54.000 .000 & & & 54.000 .000 \\
\hline Biaya listrik air telp & 35.000 .000 & & & 35.000 .000 \\
\hline Sumbangan HUT RI & 10.000 .000 & 10.000 .000 & & 0 \\
\hline Biaya alat kantor & 75.000 .000 & & & 75.000 .000 \\
\hline $\begin{array}{l}\text { Biaya seragam satpam } \\
\text { dan keselamatan kerja }\end{array}$ & 60.000 .000 & & & 60.000 .000 \\
\hline PBB dan materai & 30.000 .000 & & & 30.000 .000 \\
\hline $\begin{array}{l}\text { Biaya makan minum } \\
\text { karyawan }\end{array}$ & 20.000 .000 & & & 20.000 .000 \\
\hline $\begin{array}{l}\text { Penyusutan aktiva } \\
\text { tetap }\end{array}$ & 20.000 .000 & & 66.000 .000 & 86.000 .000 \\
\hline
\end{tabular}




\begin{tabular}{|c|c|c|c|c|}
\hline Pos rekening & $\begin{array}{c}\text { Lap keu } \\
\text { komersial }\end{array}$ & Koreksi + & Koreksi - & Lap keu fiskal \\
\hline $\begin{array}{l}\text { Premi asuransi } \\
\text { kebakaran }\end{array}$ & 25.000 .000 & & & 25.000 .000 \\
\hline Premi asuransi jiwa & 15.000 .000 & & & 15.000 .000 \\
\hline $\begin{array}{l}\text { Premi asuransi } \\
\text { kesehatan }\end{array}$ & 20.000 .000 & & & 20.000 .000 \\
\hline $\begin{array}{l}\text { Biaya pengobatan } \\
\text { rumah sakit }\end{array}$ & 30.000 .000 & 30.000 .000 & & 0 \\
\hline $\begin{array}{l}\text { Bantuan utk } \\
\text { masyarakat sekitar }\end{array}$ & 40.000 .000 & 40.000 .000 & & 0 \\
\hline $\begin{array}{l}\text { Biaya rekreasi } \\
\text { Biaya luar usaha }\end{array}$ & 50.000 .000 & 50.000 .000 & & 0 \\
\hline $\begin{array}{l}\text { Biaya perawatan } \\
\text { gedung }\end{array}$ & 20.000 .000 & 20.000 .000 & & 0 \\
\hline $\begin{array}{l}\text { Biaya pengurusan } \\
\text { tanah dijual }\end{array}$ & 35.000 .000 & 35.000 .000 & & 0 \\
\hline Rugi selisih kurs & 15.000 .000 & & & 15.000 .000 \\
\hline Pendapatan luar usaha & & & & \\
\hline Rp 70.000.000 & & & & \\
\hline Sewa gudang & 90.000 .000 & & 90.000 .000 & 0 \\
\hline Laba penjualan tanah & 80.000 .000 & & 80.000 .000 & 0 \\
\hline Sewa mesin & 40.000 .000 & & & 40.000 .000 \\
\hline Bunga deposito & 25.000 .000 & & 25.000 .000 & 0 \\
\hline Dividen & 50.000 .000 & & 50.000 .000 & 0 \\
\hline Laba neto usaha & 875.000 .000 & 266.000 .000 & 311.000 .000 & 830.000 .000 \\
\hline
\end{tabular}

\section{Sumber diolah sendiri}

Dari analisa perhitungan Laporan Rekonsiliasi Fiskal PT XYZ Jumlah bruto penghasilan usaha Rp 9.500.000.000 ditambah penghasilan lain (final) dan bukan objek Pajak Penghasilan sebesar Rp 285.000.000 masih di bawah 50 milyar, sehingga Wajib Pajak PT XYZ berhak mendapatkan fasilitas pengurangan $50 \%$ sesuai dengan Undang Undang Pajak No 36 Tahun 2008 Penghasilan Pasal 31 E, namun terbatas atas Penghasilan kena Pajak bagian dari Rp 4.8 milyar. 
Penghasilan Kena Pajak atas peredaran usaha Rp 4.8 milyar (4.8 milyar : 9.5 M) x Rp 830.000.000= Rp 419.368.370, PPH terutang 25 \% x 50 \% x Rp $419.368 .370=$ Rp 52.421.04. Sisa Penghasilan Kena Pajak yangg tidak mendapatkan fasilitas pengurangan $50 \%$ adalah $\operatorname{Rp} 830.000 .000-R p 419.368 .370=R p$ 410.631.630, dan PPH terutang $25 \%$ x Rp 410.631.630.000 = Rp 102.675.900

Total PPH terutang sebesar Rp 52. 421.046 + 102.675.900 = Rp155.096.946

PPH badan terutang

Rp 155.096.946

Kredit pajak

PPH pasal $22 \quad$ Rp 25.000.000

PPH pasal $23 \quad$ Rp 600.000

PPH pasal $25 \quad \underline{\operatorname{Rp} 18.000 .000}$

Total kredit pajak

$\underline{\text { Rp } 43.600 .000}$

PPH kurang bayar pasal 29 th 2016

Rp 111.496 .946

PPH 25 setelah SPT tahun 2016 dimasukkan (Rp 155.096.946 - PPH yg dipotong ( Rp 25.000.000 + Rp 600.000) : 12 bulan = Rp 10.791.412

Catatan Pajak penghasilan Pasal 21 Rp 6.000.000 bukan kredit pajak karena pajak tersebut pajak karyawan yang dipotong oleh PT XYZ. Pajak Penghasilan pasal 4 ayat 2 Rp 6.000.000 atas pembayaran sewa gedung bukan kredit pajak karena pajak tsb milik penerima sewa dipotong oleh PT XYZ. Pajak Penghasilan pasal 4 ayat 2 Rp 9.000.000 atas penerimaan sewa gudang bukan merupakan kredit pajak meskipun beban Pajak Penghasilan PT XYZ karena Pajak Penghasilan tersebut bersifat final

\section{SIMPULAN}

Berdasarkan hasil analisa perhitungan terhadap perhtungan Rekonsilasi Fiskal terhada Laporan Keuangan PT XYZ , maka dapat ditarik kesimpulan sebagai berikut. (1)Perhitngan rekonsilasi fiskal terhadap Lapora keuangan PT XYZ sangat perlu dilakukan karena dapat membantu dalam rangka perhitungan pajak penghasilan badan sehingga Perusahaan PT XYZ Nusa dapat melakukan 
pembayaran pajak penghasilan badan sesuai dengan peraturan perpajakan yang berlaku.

PT XYZ telah membuat perhitungan Laporan Rekonsiliasi dalam rangka perhitungan Pajak Penghasilan Badan dari laporan Laba/Rugi fiskal untuk 31 Desember 2016 dengan Laba bersih sebelum pajak berdasarkan perhitungan dalam laporan laba-rugi komersial 31 Desember yang diperoleh PT sebesar Rp.875.000.000,-. Kemudian setelah dilakukan perhitungan rekonsilasi fiskal atas laporan laba rugi komersial, laba bersih sebelum pajak menurut fiskal yang dimiliki PT XYZ adalah sebesar Rp. 830.000.000,- Perhitungan pajak penghasilan badan PT XYZ telah dilakukan sesuai tarif pajak yang berlaku berdasarkan peredaran bruto perusahaan dan dengan menggunakan laba bersih sebelum pajak menurut fiskal.

\section{PUSTAKA ACUAN}

Edy Supriyanto, Akutansi Perpajakan, Graha Ilmu. Jakarta 2013

Laporan Keuangan PT XYZ 2016. Jakarta

Siti Resmi, Perpajakan, Penerbit Salemba Empat Jakarta 2014

Soemitro, Rohmat, dalam (Mardiasmo) Perpajakan, Penerbit BPFE Yogyakarta 2016

Undang Undang Nomor 16 tahun 2009 tentang perubahan tentang Ketentuan Umum dan Tata cara Perpajakan

Undang Undang Nomor 36 Tahun 2008 tentang Pajak Penghasilan

Analisis terhadap koreksi fiskal pajak penghasilan pada PT Bitung MinaUtama di kota Bitung Ryan C.C Languju, Jantje J. Tinangon, Inggriani Elim Vol 2, No 3 (2014) https://ejournal.unsrat.ac.id/index.php/emba/article/view/5782

Analisis Rekonsiliasi Fiskal atas laba rugi dalam penentuan pajak penghasilan ( PPh ) terutang Empud Syarifuddin, Toni Andrianto, Miftahudin Mifftahudin Vol $1, \quad$ No $\quad 1 \quad$ (2014) http://jurnal.stiekesatuan.ac.id/index.php/joma/article/view/795 